\title{
Correction to: Detecting neurodegenerative pathology in multiple sclerosis before irreversible brain tissue loss sets in
}

Jeroen Van Schependom ${ }^{1,2}$, Kaat Guldolf ${ }^{1}$, Marie Béatrice D'hooghe ${ }^{1,3}$, Guy Nagels ${ }^{1,3}$ and Miguel D'haeseleer ${ }^{1,3^{*}}$

\section{Correction to: Transl Neurodegener \\ https://doi.org/10.1186/s40035-019-0178-4}

In the original publication of this article [1], the following statement should be added in the Acknowledgement section:

This paper has been published with the support of the Universitaire Stichting van België.

\section{Author details \\ 'Neurology Department, Universitair Ziekenhuis Brussel; Center for \\ Neurosciences, Vrije Universiteit Brussel, Laarbeeklaan 101, 1090 Brussel, Belgium. ${ }^{2}$ Radiology Department Universitair Ziekenhuis Brussel, Brussels, \\ Belgium. ${ }^{3}$ Nationaal Multiple Sclerose Centrum, Melsbroek, Belgium.}

Published online: 03 January 2020

\section{Reference}

1. Van Schependom, et al. Detecting neurodegenerative pathology in multiple sclerosis before irreversible brain tissue loss sets in. Transl Neurodegener. 2019;8:37.

\section{The original article can be found online at https://doi.org/10.1186/s40035-} 019-0178-4

* Correspondence: miguel.dhaeseleer@uzbrussel.be

${ }^{1}$ Neurology Department, Universitair Ziekenhuis Brussel; Center for

Neurosciences, Vrije Universiteit Brussel, Laarbeeklaan 101, 1090 Brussel,

Belgium

${ }^{3}$ Nationaal Multiple Sclerose Centrum, Melsbroek, Belgium

Full list of author information is available at the end of the article

(c) The Author(s). 2020 Open Access This article is distributed under the terms of the Creative Commons Attribution 4.0 International License (http://creativecommons.org/licenses/by/4.0/), which permits unrestricted use, distribution, and reproduction in any medium, provided you give appropriate credit to the original author(s) and the source, provide a link to the Creative Commons license, and indicate if changes were made. The Creative Commons Public Domain Dedication waiver (http://creativecommons.org/publicdomain/zero/1.0/) applies to the data made available in this article, unless otherwise stated. 